Article

\title{
Four-component one-pot synthesis of unsymmetrical polyhydroquinoline derivatives using 3-methyl-1-sulfonic acid imidazolium hydrogen sulfate as a catalyst
}

\author{
Nader Ghaffari Khaligh a,b,* \\ a Department of Chemistry, Qaemshahr Branch, Islamic Azad University, Qaemshahr, 47651-61964, Iran \\ ${ }^{\mathrm{b}}$ Research House of Professor Reza, Education Guilan, District 1, Rasht, 41569-17139, Iran
}

\section{A R T I C L E I N F O}

Article history:

Received 12 December 2013

Accepted 15 January 2014

Published 20 July 2014

Keywords:

Unsymmetrical polyhydroquinoline Brönsted acidic ionic liquid catalyst

Multicomponent reaction

Solvent-free condition

\begin{abstract}
A B S T R A C T
3-Methyl-1-sulfonic acid imidazolium hydrogen sulfate has been used as an efficient, halogen-free, and reusable Brönsted acidic ionic liquid catalyst for the synthesis of ethyl-4-aryl/heteryl-hexahydro-trimehtyl-5-oxoquinoline-3-carboxylates via the one-pot condensation of dimedone with ar$\mathrm{yl} /$ heteryl aldehydes, ethyl acetoacetate, and ammonium acetate under solvent-free conditions. This method has the advantage of being clean and simple, as well as providing the desired product in high yield over a short reaction time. Furthermore, the catalyst could be recycled and reused four times without any discernible reduction in activity.
\end{abstract}

(C) 2014, Dalian Institute of Chemical Physics, Chinese Academy of Sciences. Published by Elsevier B.V. All rights reserved.

have also been used in a number of other therapeutic applications where they have exhibited neuroprotectant and platelet anti-aggregatory activity, as well as being used as cerebral anti-ischemic agents in the treatment of Alzheimer's disease and chemo-sensitizers in tumor therapy [24,25]. Several procedures have been reported for the preparation of polyhydroquinolines, including the use of microwave irradiation [26], sonication [27], and a variety of different catalysts [28-36].

Ionic liquids possess a range of important and unique properties such as low volatility, nonflammability, high thermal stability, negligible vapor pressure, and the ability to dissolve a broad spectrum of materials [37]. Task-specific ionic liquids (TSILs) have been used as excellent alternatives to organic solvents, as well as environmentally benign catalysts and reagents for research in both academia and industry [38]. Brönsted acidic ionic liquids were originally synthesized to replace mineral liquid acids such as $\mathrm{H}_{2} \mathrm{SO}_{4}$ and $\mathrm{HCl}$ in chemical procedures [39]. The introduction of Brönsted-acidic functional

\footnotetext{
*Corresponding author. Tel: +98-2166431738; Fax: +98-2166934046; E-mail: ngkhaligh@guilan.ac.ir, ngkhaligh@gmail.com 
groups to the cations or anions of ionic liquids, especially $\mathrm{SO}_{3} \mathrm{H}$ and $\mathrm{SO}_{4} \mathrm{H}$ functional groups, leads to an obvious increase in their acidity and water solubility [40-42]. Furthermore, the polar nature of these functional groups makes their application under solvent-free conditions particularly attractive. TSILs have attracted considerable attention in terms of their application to catalytic reactions, because the TSIL and product exist in two different phases, which makes it easy for the product to be isolated and the TSIL to be recycled. Ionic liquids have been used extensively as catalysts under solvent-free conditions for the four-component synthesis of polyhydroquinoline derivatives using a Hantzsch reaction. In 2004, Ji et al. [31] performed a four-component Hantzsch reaction and reported that the use of the ionic liquid [HMIm] $\mathrm{BF}_{4}$ under solvent-free conditions shortened the reaction time to a few minutes at $90{ }^{\circ} \mathrm{C}$ and increased the yields up to $96 \%$. Ionic liquids typically consist of halogen-containing anions, which have limited their overall utility from a "green chemistry" perspective, and research towards the development of greener ionic liquids using halogen-free anions such as phosphate or sulfate anion has been reported in the literature, together with studies pertaining to the effect of different anions on the toxicology of these liquids [43-48].

3-Methyl-1-sulfonic acid imidazolium hydrogen sulfate [(MSAIm) $\left.\mathrm{HSO}_{4}\right]$, which consists of a sulfonic acid group with an imidazolium cation and hydrogen sulfate anion, was recently synthesized as a halogen-free acidic ionic liquid, and investigated as a catalyst for the protection of hydroxyl groups [49] and the synthesis of coumarins via the Pechmann reaction [50]. In the current study, we have developed and optimized a (MSAIm) $\mathrm{HSO}_{4}$-catalyzed process for the synthesis of ethyl-4aryl-hexahydro-trimehtyl-5-oxoquinoline-3-carboxylate derivatives, which could exhibit good dye properties, as well as interesting biological and pharmaceutical activity.

\section{Experimental}

\subsection{General}

All the chemicals were purchased from Fluka AG, Merck, and Synthetic Chemicals Ltd. The reactions were monitored by TLC using silica TLC plates and the product purities were determined by GC-MS on an Agilent GC-Mass-6890 instrument under ionization conditions of $70 \mathrm{eV}$. Fourier transform infrared (FT-IR) spectra were recorded on a Perkin-Elmer 781 FT-IR spectrometer and a Bruker Equinox 55 system. The FT-IR spectra of solid samples were recorded as $\mathrm{KBr}$ disks, whereas the spectra of liquid samples were recorded neat in the range of 4000-400 $\mathrm{cm}^{-1}$. ${ }^{1} \mathrm{H}$ NMR spectra were recorded on a Bruker Avance $400 \mathrm{MHz}$ instrument using deuterated DMSO or chloroform containing TMS as an internal reference standard. Mass spectra were recorded on a PESciex model API 3000 instrument. Microanalyses were performed on a Perkin-Elmer 240-B microanalyzer. Melting points (m.p.) were recorded on a Büchi B-545 apparatus in open capillary tubes.

\subsection{Typical procedure for the preparation of the}

ethyl-4-aryl-hexahydro-trimehtyl-5-oxoquinoline-3-carboxylate derivatives (4)

The (MSAIm) $\mathrm{HSO}_{4}$ catalyst (10 mg, $3.8 \mathrm{~mol} \%$ ) was added to a mixture of dimedone ( $1 \mathrm{mmol})$, ethyl acetoacetate $(1 \mathrm{mmol})$, aryl/heteryl aldehyde (1 mmol) and ammonium acetate (1 $\mathrm{mmol}$ ), and the resulting mixture was stirred for an appropriate time period at $50{ }^{\circ} \mathrm{C}$ under solvent-free conditions. When the reaction mixture existed as a solid, the material was placed in a porcelain dish and ground with a mortar at $50{ }^{\circ} \mathrm{C}$. Upon completion of the reaction, as determined by TLC, the mixture was cooled to room temperature. The reaction product was subsequently extracted with ethyl acetate (EtOAc, $3 \times 5 \mathrm{~mL}$ ) and the (MSAIm) $\mathrm{HSO}_{4}$ catalyst was recovered. The Brönsted acidic ionic liquid was immiscible with EtOAc, and could therefore be conveniently separated from the products via a simple phase separation. The recovered catalyst was washed with EtOAc $(2 \times 5 \mathrm{~mL})$ before being dried at ambient temperature and reused in the next run. The combined EtOAc extracts were evaporated under reduced pressure to give the crude products as solids, which were crystallized from ethanol to afford the pure polyhydroquinoline derivatives.

\subsection{Spectral data of new products}

Ethyl-4-(3-ethoxy-4-hydroxyphenyl)-1,4,5,6,7,8-hexahydro2,7,7-trimethyl-5-oxoquinoline-3-carboxylate (4q). White solid; m.p. $=195-197^{\circ} \mathrm{C}$; FT-IR (KBr): $v_{\max }=3282,3203,3077$, 2958, 1689, 1615, 1511, 1488, $1215 \mathrm{~cm}^{-1}$; ${ }^{1} \mathrm{H}$ NMR (400 MHz, DMSO-d6): $\delta=0.87(\mathrm{~s}, 3 \mathrm{H}), 1.01(\mathrm{~s}, 3 \mathrm{H}), 1.15(\mathrm{t}, J=7.2 \mathrm{~Hz}, 3 \mathrm{H})$, $1.28(\mathrm{t}, J=6.8 \mathrm{~Hz}, 3 \mathrm{H}), 1.98(\mathrm{~d}, J=16 \mathrm{~Hz}, 1 \mathrm{H}), 2.16(\mathrm{~d}, J=16.4$ $\mathrm{Hz}, 1 \mathrm{H}), 2.25-2.43(\mathrm{~m}, 5 \mathrm{H}), 3.85-3.91(\mathrm{~m}, 2 \mathrm{H}), 3.96-4.01(\mathrm{~m}$, $2 \mathrm{H}), 4.73(\mathrm{~s}, 1 \mathrm{H}), 6.48-6.51(\mathrm{~m}, 1 \mathrm{H}), 6.57(\mathrm{~d}, J=8 \mathrm{~Hz}, 1 \mathrm{H}), 6.68$ (d, $J=8 \mathrm{~Hz}, 1 \mathrm{H}), 8.53(\mathrm{~s}, 1 \mathrm{H}), 8.98(\mathrm{~s}, 1 \mathrm{H}) \mathrm{ppm}$; MS (ESI) $\mathrm{m} / z=$ $400[\mathrm{M}+\mathrm{H}]^{+}$; Anal. Calcd. for $\mathrm{C}_{23} \mathrm{H}_{29} \mathrm{NO}_{5}$ : C 69.15\%, H 7.32\%, N 3.51\%; Found: C 69.27\%, H 7.64\%, N 3.42\%.

Ethyl-4-(5-bromo-2-hydroxyphenyl)-1,4,5,6,7,8-hexahydro2,7,7-trimethyl-5-oxoquinoline-3-carboxylate (4r). Pale yellow solid; m.p. $=226-228^{\circ} \mathrm{C}$; FT-IR $(\mathrm{KBr}): v_{\max }=3318,3253,3093$, 2962, 1654, 1606, 1590, 1489, 1230, $619 \mathrm{~cm}^{-1}$; ${ }^{1} \mathrm{H}$ NMR (400 MHz, DMSO- $\left.d_{6}\right): \delta=0.84(\mathrm{~s}, 3 \mathrm{H}), 1.01-1.06(\mathrm{~m}, 6 \mathrm{H}), 2.05(\mathrm{~d}, J=$ $16.4 \mathrm{~Hz}, 1 \mathrm{H}), 2.23(\mathrm{~d}, J=16.4 \mathrm{~Hz}, 1 \mathrm{H}), 2.25-2.43(\mathrm{~m}, 5 \mathrm{H})$, 3.87-3.97 (m, 2H), 4.89 (s, 1H), $6.65(\mathrm{~d}, J=8.8 \mathrm{~Hz}, 1 \mathrm{H}), 6.98(\mathrm{~d}$, $J=8.8 \mathrm{~Hz}, 1 \mathrm{H}), 7.07-7.10(\mathrm{~m}, 1 \mathrm{H}), 9.28(\mathrm{~s}, 1 \mathrm{H}), 9.58(\mathrm{~s}, 1 \mathrm{H})$ ppm; MS (ESI) $m / z=435[\mathrm{M}+\mathrm{H}]+$; Anal. Calcd. for $\mathrm{C}_{21} \mathrm{H}_{24} \mathrm{BrNO}_{4}$ : C 58.07\%, H 5.57\%, N 3.22\%; Found: C 58.26\%, H 5.34\%, N $3.41 \%$.

Ethyl-4-(3,5-dibromo-2-hydroxyphenyl)-1,4,5,6,7,8-hexahydro-2,7,7-trimethyl-5-oxoquinoline-3-carboxylate (4s). Pale yellow solid; m.p. $=277-279{ }^{\circ} \mathrm{C}$; FT-IR $(\mathrm{KBr}): v_{\max }=3287,3212$, 3073, 2957, 1635, 1614, 1577, 1485, 1225, $667 \mathrm{~cm}^{-1}$; ${ }^{1} \mathrm{H}$ NMR (400 MHz, DMSO- $\left.d_{6}\right): \delta=0.94(\mathrm{~s}, 3 \mathrm{H}), 1.01-1.05(\mathrm{~m}, 6 \mathrm{H}), 2.13$ (d, $J=16 \mathrm{~Hz}, 1 \mathrm{H}), 2.28-2.44(\mathrm{~m}, 6 \mathrm{H}), 3.88-3.95(\mathrm{~m}, 2 \mathrm{H}), 4.82(\mathrm{~s}$, 1H), 6.88-6.91 (m, 1H ), 7.48-7.50 (m, 1H), $9.56(\mathrm{~s}, 1 \mathrm{H}), 9.86(\mathrm{~s}$, 1H) ppm; MS (ESI) $m / z=513$ [M]+; Anal. Calcd. for $\mathrm{C}_{21} \mathrm{H}_{23} \mathrm{Br}_{2} \mathrm{NO}_{4}$ : C 49.15\%, H 4.52\%, N 2.73\%; Found: C 49.26\%, H $4.71 \%$, N 2.60\%. 
Ethyl-4-(5-chloro-2-hydroxyphenyl)-1,4,5,6,7,8-hexahydro2,7,7-trimethyl-5-oxoquinoline-3-carboxylate (4t). Pale yellow solid; m.p. $=208-210^{\circ} \mathrm{C}$; FT-IR (KBr): $v_{\max }=3317,3253,3096$, 2961, 1654, 1608, 1591, 1490, 1230, $643 \mathrm{~cm}^{-1}$; ${ }^{1} \mathrm{H}$ NMR (400 MHz, DMSO- $\left.d_{6}\right): \delta=0.84(\mathrm{~s}, 3 \mathrm{H}), 1.01-1.05(\mathrm{~m}, 6 \mathrm{H}), 2.06(\mathrm{~d}, J=$ $16 \mathrm{~Hz}, 1 \mathrm{H}), 2.22-2.44(\mathrm{~m}, 6 \mathrm{H}), 3.89-3.94(\mathrm{~m}, 2 \mathrm{H}), 4.91(\mathrm{~s}, 1 \mathrm{H})$, $6.70(\mathrm{~d}, J=8.4 \mathrm{~Hz}, 1 \mathrm{H}), 6.85(\mathrm{~d}, J=8.4 \mathrm{~Hz}, 1 \mathrm{H}), 6.96-6.99(\mathrm{~m}$, 1H), 9.30 (s, 1H), 9.58 (s, 1H) ppm; MS (ESI) $m / z=390[\mathrm{M}+\mathrm{H}]^{+}$; Anal. Calcd. for $\mathrm{C}_{21} \mathrm{H}_{24} \mathrm{ClNO}_{4}$ : C $64.69 \%$, H 6.20\%, N 3.59\%; Found: C 64.53\%, H 6.33\%; N 3.72\%.

\section{Results and discussion}

The condensation of dimedone (1) with 4-chlorobenzaldehyde (2c), ethyl acetoacetate (3), and ammonium acetate was selected as a model reaction, and several different reaction parameters, including the amount of (MSAIm) $\mathrm{HSO}_{4}$ (i.e., 5, 10, and $20 \mathrm{mg}$ ), different types of solvent (i.e., $\mathrm{CH}_{2} \mathrm{Cl}_{2}, \mathrm{CH}_{3} \mathrm{CN}$, $\mathrm{MeOH}, \mathrm{EtOH}$, and $\mathrm{H}_{2} \mathrm{O}$ ) and solvent-free conditions, and various reaction temperatures (i.e., room temperature, reflux for solvents, $50-100^{\circ} \mathrm{C}$ for solvent-free conditions) were evaluated to optimize the reaction conditions (Table 1).

When the model reaction was carried out in ethanol at reflux in the presence of $20 \mathrm{mg}$ (MSAIm) $\mathrm{HSO}_{4}$, the desired product $4 \mathrm{c}$ was obtained in $72 \%$ yield within $1 \mathrm{~h}$. Pleasingly, when the reaction was conducted under solvent-free conditions at 50 ${ }^{\circ} \mathrm{C}$ in the presence of $10 \mathrm{mg}$ of (MSAIm) $\mathrm{HSO}_{4}, \mathbf{4 c}$ was formed in 92\% yield within 17 min (Scheme 1), with the solvent-free conditions effectively facilitating the condensation reactions involved in the Hantzsch reaction to a much greater extent. These results suggested that the microenvironment of the solvent-free system was different to that of the solution-based system, resulting in the observed improvement in the yield of the Hantzsch condensation reaction [51].

To evaluate the scope of this transformation over the (MSAIm) $\mathrm{HSO}_{4}$ catalyst, we evaluated the conversion of a variety of different aryl/heteryl aldehydes to the corresponding ethyl-4-aryl-1,4,5,6,7,8-hexahydro-2,7,7-trimethyl-5-oxoquinoli ne-3-carboxylate derivatives $(\mathbf{4 a - 4 x})$ under the optimized conditions (Table 2). Aryl aldehydes bearing electron-donating or electron-withdrawing substituents reacted smoothly to afford the corresponding polyhydroquinolines in good to high yields over short reaction time (Table 2, entries 1-21). The position and electronic properties of the substituent on aromatic aldehyde had a significant impact on the yield of the polyhydroquinoline and the reaction time. For example, aryl alde-
Table 1

Optimization of the reaction conditions for the synthesis of ethyl4-(4-chlorophenyl)-1,4,5,6,7,8-hexahydro-2,7,7-trimethyl-5-oxoquinoli ne-3-carboxylates in the presence of (MSAIm) $\mathrm{HSO}_{4}$.

\begin{tabular}{lccccc}
\hline Entry & Solvent & $\begin{array}{c}\text { Amount of } \\
\text { (MSAIm) } \mathrm{HSO}_{4}(\mathrm{mg})\end{array}$ & $\begin{array}{c}\text { Temperature } \\
\left({ }^{\circ} \mathrm{C}\right)\end{array}$ & $\begin{array}{c}\text { Time } \\
(\mathrm{min})\end{array}$ & $\begin{array}{c}\text { Yield* } \\
(\%)\end{array}$ \\
\hline 1 & $\mathrm{CH}_{2} \mathrm{Cl}_{2}$ & 20 & r.t. & 60 & 14 \\
2 & $\mathrm{CH}_{2} \mathrm{Cl}_{2}$ & 20 & reflux & 60 & 32 \\
3 & $\mathrm{CH}_{3} \mathrm{CN}$ & 20 & r.t. & 60 & 34 \\
4 & $\mathrm{CH}_{3} \mathrm{CN}$ & 20 & reflux & 60 & 52 \\
5 & $\mathrm{CH}_{3} \mathrm{OH}$ & 20 & r.t. & 60 & 39 \\
6 & $\mathrm{CH}_{3} \mathrm{OH}$ & 20 & reflux & 60 & 60 \\
7 & $\mathrm{C}_{2} \mathrm{H}_{5} \mathrm{OH}$ & 20 & r.t. & 60 & 48 \\
8 & $\mathrm{C}_{2} \mathrm{H}_{5} \mathrm{OH}$ & 20 & reflux & 60 & 72 \\
9 & $\mathrm{H}_{2} \mathrm{O}$ & 20 & r.t. & 60 & 32 \\
10 & $\mathrm{H}_{2} \mathrm{O}$ & 20 & reflux & 60 & 68 \\
11 & solvent-free & 20 & r.t. & 60 & 72 \\
12 & solvent-free & 20 & 50 & 15 & 92 \\
13 & solvent-free & 10 & 50 & 17 & 92 \\
14 & solvent-free & 5 & 50 & 20 & 87 \\
15 & solvent-free & 10 & 80 & 15 & 92 \\
16 & solvent-free & 10 & 100 & 20 & 83 \\
\hline
\end{tabular}

Reaction conditions: dimedone $1 \mathrm{mmol}$, 4-chlorobenzaldehyde $1 \mathrm{mmol}$, ethyl acetoacetate $1 \mathrm{mmol}$, ammonium acetate $1 \mathrm{mmol}$.

* GC-MS yield.

hydes bearing electron-donating substituents required longer reaction time (Table 2, entries 7-9, 13, 16-20). Furthermore, when the aldehyde contained a para-OH group, the corresponding product was formed in $86 \%$ yield within $25 \mathrm{~min}$, whereas the use of a para- $\mathrm{NO}_{2}$ group led to an increase in the rate of the reaction, with the corresponding product with $96 \%$ yield in only 15 min (Table 2, entries 8 and 10). These results demonstrated that aldehydes bearing electron-withdrawing groups (i.e., $-\mathrm{NO}_{2}$ and halogens) were more active towards the reaction than those bearing electron-donating groups (i.e., $\mathrm{CH}_{3} \mathrm{O}-$ and $\mathrm{HO}-$ ). The use of aldehydes bearing substituents at the ortho-position of their phenyl ring gave lower yields of the products than those bearing the same substituents at the $p a-$ ra-position, most likely because of steric hindrance (Table 2, entries 3,10,11, and 14). The use of aliphatic aldehydes as substrates for the reaction was unsuccessful, and analysis of the reaction mixtures by TLC and GC-MS revealed numerous byproducts. It is noteworthy that when the model reaction was conducted in the absence of catalyst under the optimized conditions for $1 \mathrm{~h}$, the yield of the product was low (22\%). The structure of the new products were established on the basis of their spectral properties (i.e., IR, ${ }^{1} \mathrm{H}$ NMR, and MS), melting points, and elemental analysis. The known products were characterized on the basis of their physical data (i.e., m.p., IR,

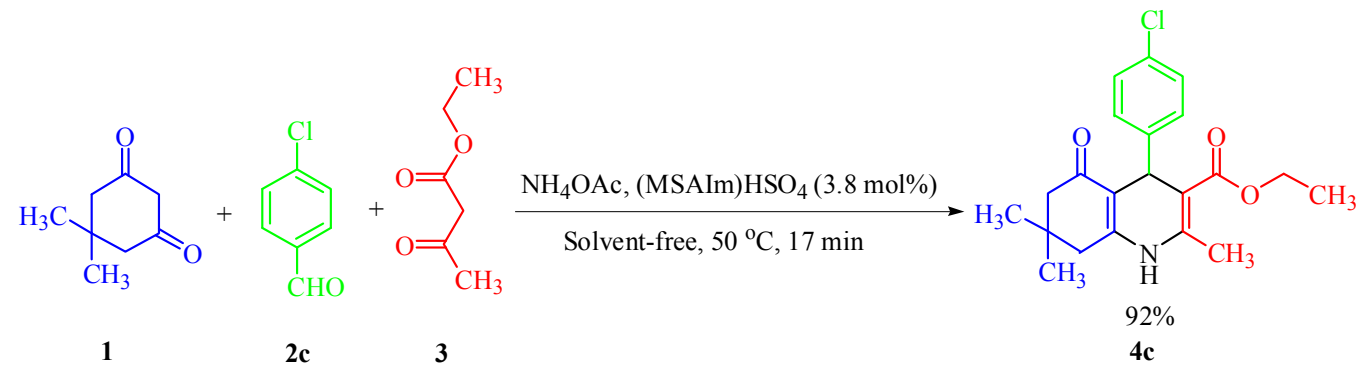

Scheme 1. Synthesis of ethyl-4-(4-chlorophenyl)-1,4,5,6,7,8-hexahydro-2,7,7-trimethyl-5-oxoquinoline-3-carboxylate (4c) in the presence of (MSAIm) $\mathrm{HSO}_{4}$. 
Table 2

Synthesis of ethyl-4-aryl/heteryl-1,4,5,6,7,8-hexahydro-2,7,7-trimethyl-5-oxoquinoline-3-carboxylates in the presence of (MSAIm)HSO ${ }_{4}$.

\begin{tabular}{|c|c|c|c|c|c|c|c|}
\hline \multirow{2}{*}{ Entry } & \multirow{2}{*}{ Substrate (2) } & \multirow{2}{*}{ Product (4) } & \multirow{2}{*}{ Time (min) } & \multirow{2}{*}{ Yield a (\%) } & \multicolumn{2}{|c|}{ m.p. $\left({ }^{\circ} \mathrm{C}\right)$} & \multirow{2}{*}{ Ref. } \\
\hline & & & & & Found & Reported & \\
\hline 1 & $\mathrm{C}_{6} \mathrm{H}_{5}-\mathrm{CHO}$ & $4 a$ & 18 & 92 & $202-204$ & $202-204$ & [28] \\
\hline 2 & $4-\mathrm{F}-\mathrm{C}_{6} \mathrm{H}_{4}-\mathrm{CHO}$ & $4 b$ & 17 & 92 & $182-184$ & $184-186$ & [28] \\
\hline 3 & $4-\mathrm{Cl}-\mathrm{C}_{6} \mathrm{H}_{4}-\mathrm{CHO}$ & $4 c$ & $17(17,17,18,18)^{\mathrm{b}}$ & $95(95,94,94,93)^{\mathrm{b}}$ & $240-242$ & $241-243$ & [29] \\
\hline 4 & $4-\mathrm{Br}-\mathrm{C}_{6} \mathrm{H}_{4}-\mathrm{CHO}$ & 4d & 17 & 94 & $250-252$ & $253-255$ & [28] \\
\hline 5 & $4-\mathrm{CH}_{3}-\mathrm{C}_{6} \mathrm{H}_{4}-\mathrm{CHO}$ & $4 e$ & 20 & 92 & $261-263$ & $260-261$ & [28] \\
\hline 6 & $4-\left(\mathrm{CH}_{3}\right)_{2} \mathrm{C}-\mathrm{C}_{6} \mathrm{H}_{4}-\mathrm{CHO}$ & 4f & 20 & 90 & $175-177$ & $179-180$ & [30] \\
\hline 7 & $4-\mathrm{CH}_{3} \mathrm{O}-\mathrm{C}_{6} \mathrm{H}_{4}-\mathrm{CHO}$ & $4 g$ & 22 & 89 & $255-257$ & $257-259$ & [28] \\
\hline 8 & $4-\mathrm{HO}-\mathrm{C}_{6} \mathrm{H}_{4}-\mathrm{CHO}$ & $4 h$ & 25 & 86 & $230-232$ & $232-234$ & [28] \\
\hline 9 & $4-\left(\mathrm{CH}_{3}\right)_{2} \mathrm{~N}-\mathrm{C}_{6} \mathrm{H}_{4}-\mathrm{CHO}$ & $4 \mathbf{i}$ & 22 & 87 & $231-233$ & $229-231$ & [28] \\
\hline 10 & $4-\mathrm{NO}_{2}-\mathrm{C}_{6} \mathrm{H}_{4}-\mathrm{CHO}$ & $4 j$ & 15 & 96 & $240-242$ & $240-242$ & [31] \\
\hline 11 & $2-\mathrm{Cl}-\mathrm{C}_{6} \mathrm{H}_{4}-\mathrm{CHO}$ & $4 k$ & 20 & 90 & $202-204$ & $208-210$ & [31] \\
\hline 12 & $2,4-\mathrm{Cl}_{2}-\mathrm{C}_{6} \mathrm{H}_{3}-\mathrm{CHO}$ & $4 \mathrm{~L}$ & 20 & 92 & $242-244$ & $241-244$ & [28] \\
\hline 13 & $3,4-\left(\mathrm{CH}_{3} \mathrm{O}\right)_{2}-\mathrm{C}_{6} \mathrm{H}_{3}-\mathrm{CHO}$ & $4 m$ & 25 & 88 & 196-198 & $198-200$ & [32] \\
\hline 14 & $2-\mathrm{NO}_{2}-\mathrm{C}_{6} \mathrm{H}_{4}-\mathrm{CHO}$ & $4 n$ & 17 & 90 & $207-209$ & $207-208$ & [32] \\
\hline 15 & $3-\mathrm{NO}_{2}-\mathrm{C}_{6} \mathrm{H}_{4}-\mathrm{CHO}$ & 40 & 17 & 94 & $182-184$ & $182-184$ & [29] \\
\hline 16 & $3-\mathrm{CH}_{3} \mathrm{O}-4-\mathrm{HO}-\mathrm{C}_{6} \mathrm{H}_{3}-\mathrm{CHO}$ & $4 p$ & 23 & 84 & $215-217$ & $219-221$ & [30] \\
\hline 17 & $2-\mathrm{C}_{2} \mathrm{H}_{5} \mathrm{O}-4-\mathrm{HO}-\mathrm{C}_{6} \mathrm{H}_{3}-\mathrm{CHO}$ & $4 q$ & 25 & 82 & $197-199$ & - & - \\
\hline 18 & $2-\mathrm{HO}-5-\mathrm{Br}-\mathrm{C}_{6} \mathrm{H}_{3}-\mathrm{CHO}$ & $4 \mathrm{r}$ & 25 & 84 & $228-230$ & - & - \\
\hline 19 & $2-\mathrm{HO}-\left(3,5-\mathrm{Br}_{2}\right)-\mathrm{C}_{6} \mathrm{H}_{3}-\mathrm{CHO}$ & $4 s$ & 25 & 86 & $280-282$ & - & - \\
\hline 20 & $2-\mathrm{HO}-5-\mathrm{Cl}-\mathrm{C}_{6} \mathrm{H}_{3}-\mathrm{CHO}$ & $4 t$ & 25 & 85 & $210-212$ & - & - \\
\hline 21 & Cinnamaldehyde & $4 x$ & 18 & 92 & $200-202$ & 204-206 & {$[28]$} \\
\hline 22 & Furfural & $4 u$ & 27 & 86 & $242-244$ & $246-248$ & [28] \\
\hline 23 & 3-Nicotinaldehyde & $4 v$ & 25 & 80 & $69-71$ & $66-67$ & [28] \\
\hline 24 & 2-Thienylaldehyde & $4 w$ & 30 & 78 & $236-238$ & $238-240$ & [28] \\
\hline
\end{tabular}

Reaction conditions: dimedone $1 \mathrm{mmol}$, aryl/heteryl aldehyde $1 \mathrm{mmol}$, ethyl acetoacetate $1 \mathrm{mmol}$, ammonium acetate $1 \mathrm{mmol},\left(\mathrm{MSAIm} \mathrm{HSO}_{4} 10 \mathrm{mg}\right.$, $50{ }^{\circ} \mathrm{C}$, solvent-free.

a Isolated yield following chromatographic purification.

${ }^{\mathrm{b}}$ Recycled Brönsted acidic ionic liquid catalyst was used.

and ${ }^{1} \mathrm{H}$ NMR) and through a comparison with authentic samples.

The recyclability of the (MSAIm) $\mathrm{HSO}_{4}$ catalyst represents one of the key advantages of the current method, and the catalyst could be recycled at least five times without any significant impact on the yield of ethyl-4-(4-chlorophenyl)-1,4,5,6,7,8hexahydro-2,7,7-trimethyl-5-oxoquinoline-3-carboxylate under the optimized conditions (Table 2, entry 3). Upon completion of the reaction, the product was extracted and new substrates were added to the reaction vessel. The progress of the reaction was monitored by TLC under the optimized conditions and this process was repeated for five runs. The results showed that there was no discernible decrease in the activity of catalyst, with yields in the range of $93 \%$ to $95 \%$ across all five runs, and an average reaction time of approximately $18 \mathrm{~min}$.

A possible mechanism has been proposed for this reaction, as shown in Scheme 2. Dimedone (1), aldehyde (2), and ethylacetoacetate (3) would be activated by the Brönsted acidic ionic liquid catalyst. Dimedone or ethyl acetoacetate would be converted to its enol form by the Brönsted acidic ionic liquid and a Knoevenagel type coupling would then take place with the activated aldehyde to afford intermediate (I) or (III). In contrast, the activated ethyl acetoacetate or activated dimedone could react with ammonium acetate to give enamine (II) or (IV). It is noteworthy that the ionic liquid would effectively provide a proton to activate the carbonyl groups of the starting material and that this proton would ultimately be transferred back to the ionic liquid in another step. Subsequent Michael addition of enamine (II) to intermediate (I) or enamine (IV) to intermediate (III) followed by sequential cyclization and dehydration reactions would afford the polyhydroquinoline product (4) [29]. In multicomponent reactions of this type, the elimination of $\mathrm{H}_{2} \mathrm{O}$ is critical, and the observed increase in the reaction rate may have occurred as a consequence of an increase in the rate of the absorption of $\mathrm{H}_{2} \mathrm{O}$ by the ionic liquid or the elimination of $\mathrm{H}_{2} \mathrm{O}$ at the high temperature of reaction.

The possible leaching of $\mathrm{H}_{2} \mathrm{SO}_{4}$ from the matrix was studied under the optimized reaction conditions. No leaching was observed under the optimized conditions. After eight recycled runs, the catalyst retained about $92 \%$ of its initial activity (data not shown).

A comparison of our results with several other results reported in the literatures for the same transformation has been provided in Table 3 to highlight the merits of the current method. It is clear that the reaction time and yields achieved with our newly developed procedure are similar to or higher than those described in the literatures. When the Hantzsch reaction was carried out in the presence of $10 \mathrm{~mol} \%$ guanidine $\mathrm{HCl}$ (organocatalyst) in ethanol at room temperature, compounds $\mathbf{4 c}, \mathbf{4 x}, \mathbf{4 u}$, and $\mathbf{4 v}$ were formed in yields of $95 \%, 90 \%$, $78 \%$, and $75 \%$, respectively, after $3 \mathrm{~h}$ [54]. Furthermore, when $10 \mathrm{~mol} \% \mathrm{~L}$-proline was used as a catalyst for the same transformation, compounds $\mathbf{4 c}, \mathbf{4 e}$, and $\mathbf{4 i}$ were formed in $91 \%$, $94 \%$, and $96 \%$ yields, respectively, after $30 \mathrm{~min}$ [29]. In contrast to both of these reports, the use of the current method gave compounds $\mathbf{4 c}, \mathbf{4 e}, \mathbf{4 i}, \mathbf{4 x}, \mathbf{4} \mathbf{u}$, and $\mathbf{4 v}$ in yields of $95 \%$, $92 \%, 87 \%, 92 \%, 86 \%$, and $80 \%$ within $17,20,22,18,27$, and $25 \mathrm{~min}$, respectively. 


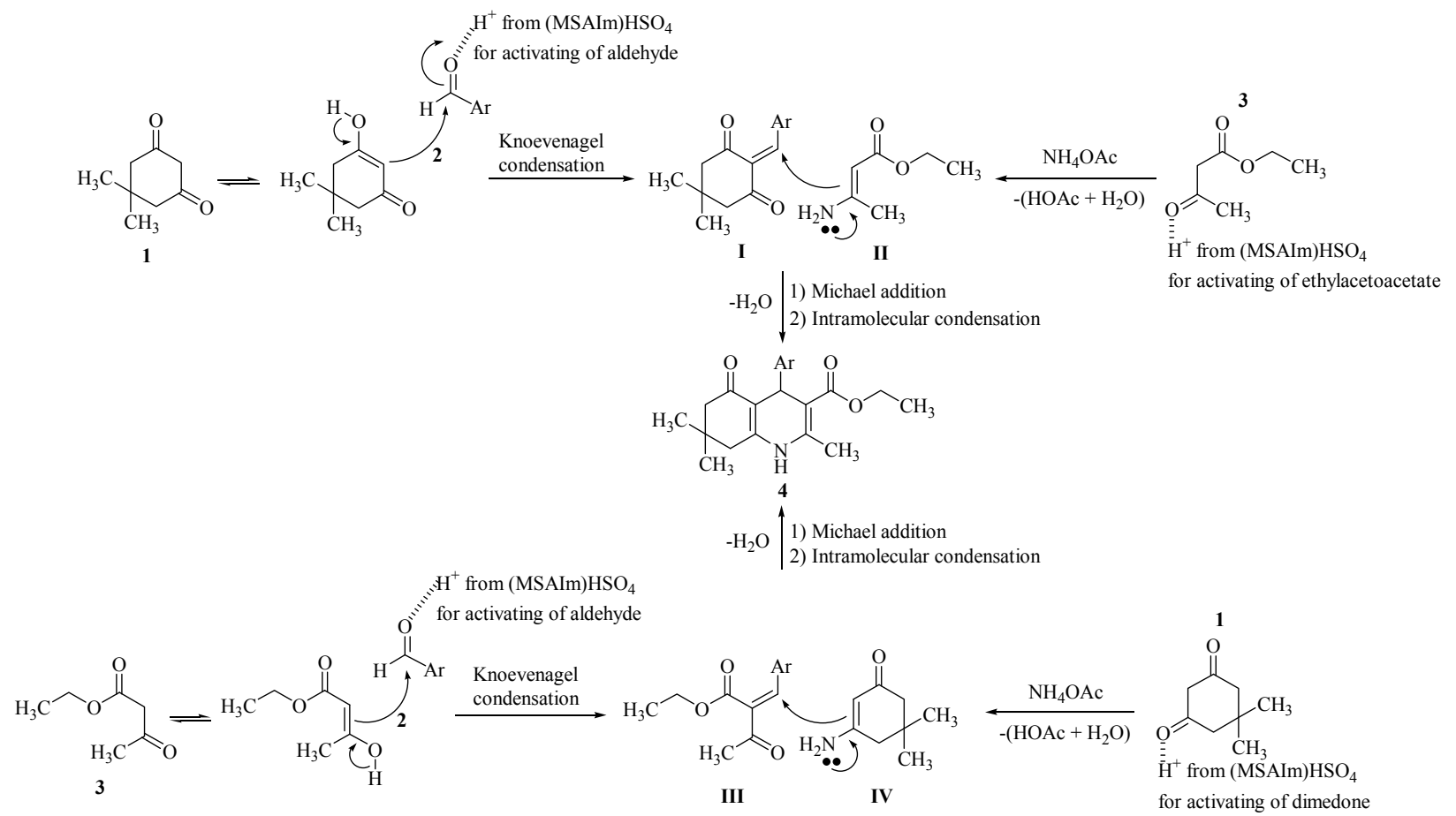

Scheme 2. A possible mechanism for the synthesis of polyhydroquinoline in the presence of (MSAIm) $\mathrm{HSO}_{4}$ under solvent-free conditions.

Table 3

Comparison of the use of different catalysts for the preparation of ethyl-4-(4-chlorophenyl)-1,4,5,6,7,8-hexahydro-2,7,7-trimethyl-5-oxoquinoline3-carboxylate.

\begin{tabular}{|c|c|c|c|c|c|c|c|c|}
\hline Entry & Catalyst & Catalyst amount & $\begin{array}{c}\text { Ammonium } \\
\text { acetate (equiv.) }\end{array}$ & Solvent & $\begin{array}{c}\text { Temperature } \\
\left({ }^{\circ} \mathrm{C}\right)\end{array}$ & $\begin{array}{l}\text { Time } \\
\text { (min) }\end{array}$ & $\begin{array}{l}\text { Isolated } \\
\text { yield (\%) }\end{array}$ & Ref. \\
\hline 1 & MCM-41 & $1 \mathrm{~mol} \%$ & 1.5 & - & 90 & 15 & 90 & {$[52]$} \\
\hline 2 & $\begin{array}{l}\text { Modified Mont. supported } \\
\qquad \text { Nano- } \mathrm{Ni}^{0}\end{array}$ & $25 \mathrm{mg}$ & 1.5 & - & r.t. & 15 & 88 & [53] \\
\hline 3 & Guanidine hydrochloride & $10 \mathrm{~mol} \%$ & 1 & EtOH & r.t. & 180 & 95 & {$[54]$} \\
\hline 4 & $\left(\mathrm{PPA}-\mathrm{SiO}_{2}\right)$ & $30 \mathrm{mg}$ & 1 & - & 80 & 45 & 92 & [55] \\
\hline 5 & [Pyridine- $\left.\mathrm{SO}_{3} \mathrm{H}\right] \mathrm{Cl}$ & $3 \mathrm{~mol} \%$ & 1.2 & - & 50 & 10 & 92 & [56] \\
\hline 6 & Trifluoroethanol (TFE) & $2 \mathrm{~mL}$ & 1 & TFE & 70 & 180 & 95 & [57] \\
\hline 7 & $\mathrm{Hf}\left(\mathrm{NPf}_{2}\right)_{4}$ & $1 \mathrm{~mol} \%$ & 1 & $\mathrm{C}_{10} \mathrm{~F}_{18}$ & 60 & 120 & 96 & {$[58]$} \\
\hline 8 & $\mathrm{FeF}_{3}$ & $5 \mathrm{~mol} \%$ & 1 & EtOH & $75-80$ & 60 & 92 & [59] \\
\hline 9 & $\operatorname{Sc}(\mathrm{OTf})_{3}$ & $5 \mathrm{~mol} \%$ & 1 & $\mathrm{EtOH}$ & r.t. & 240 & 89 & [60] \\
\hline 10 & $\mathrm{~K}_{7}\left[\mathrm{PW}_{11} \mathrm{CoO}_{40}\right]$ & $30 \mathrm{mg}$ & 1 & $\mathrm{MeCN}$ & reflux & 30 & 85 & [61] \\
\hline 11 & [2-MPyH]OTf & $1 \mathrm{~mol} \%$ & 1 & $\mathrm{H}_{2} \mathrm{O}$ & r.t. & 5 & 97 & [62] \\
\hline 12 & $\mathrm{Yb}(\mathrm{OTf})_{3}$ & $5 \mathrm{~mol} \%$ & 1 & EtOH & r.t. & 240 & $95^{\mathrm{a}}$ & [28] \\
\hline 13 & CAN & $5 \mathrm{~mol} \%$ & 1 & EtOH & r.t. & 35 & 88 & [63] \\
\hline 14 & L-Proline & $10 \mathrm{~mol} \%$ & 1 & - & r.t. & 30 & 91 & [29] \\
\hline 15 & $\begin{array}{l}\text { Bakers' yeast, D-glucose, } \\
\text { phosphate buffer }\end{array}$ & $\begin{array}{c}200 \mathrm{mg}, 300 \mathrm{mg}, \\
5 \mathrm{~mL}(\mathrm{pH}=7)\end{array}$ & 1 & - & r.t. & 1440 & $79^{b}$ & [64] \\
\hline 16 & Nano-Ni & $10 \mathrm{~mol} \%$ & 1.5 & - & microwave $(540 \mathrm{~W})$ & 1 & 90 & [65] \\
\hline 17 & Nano-Pd & $4 \mathrm{~mol} \%$ & 2 & THF & reflux & 240 & 87 & [66] \\
\hline 18 & - & - & 1.5 & EtOH & r.t. & 360 & 84 & {$[30]$} \\
\hline 19 & $\mathrm{HClO}_{4}-\mathrm{SiO}_{2}$ & $50 \mathrm{mg}$ & 1.5 & - & 90 & 10 & 95 & [32] \\
\hline 20 & {$[\mathrm{Dsim}] \mathrm{HSO}_{4}$} & 20 mg (3 mol\%) & 1.2 & - & 50 & 25 & 89 & [67] \\
\hline 21 & $\left(\mathrm{MSAIm} \mathrm{HSO}_{4}\right.$ & $10 \mathrm{mg}$ (3.4 mol\%) & 1 & - & 60 & 17 & 95 & this work \\
\hline
\end{tabular}

Reaction conditions: dimedone $1 \mathrm{mmol}$, 4-chlorobenzaldehyde $1 \mathrm{mmol}$, ethyl acetoacetate $1 \mathrm{mmol}$.

a Data are for 4-bromobenzaldehyde.

b Data are for benzaldehyde.

Furthermore, the use of $3 \mathrm{~mol} \%$ [pyridine- $\left.\mathrm{SO}_{3} \mathrm{H}\right] \mathrm{Cl}$ as a catalyst for the procedure at $50{ }^{\circ} \mathrm{C}$ gave compounds $4 \mathbf{c}, \mathbf{4 i}, \mathbf{4 g}$, and 4h in yields of $92 \%, 95 \%, 95 \%$, and $94 \%$ with reaction time of $10,8,10$, and $8 \mathrm{~min}$, respectively [56], whereas the used of 3 mol\% [2-MPyH]OTf as the catalyst at room temperature gave the same compounds in 97, 98, 96 and $95 \%$ yields with reaction time of 5, 1, 6, and 6 min, respectively [62]. Pleasingly, the use of the current method under solvent-free conditions gave 4c, $\mathbf{4 i}, \mathbf{4 g}$, and $\mathbf{4 h}$ in $95 \%, 96 \%, 89 \%$, and $86 \%$, yields within $17,15,22$, and $25 \mathrm{~min}$, respectively. 
Some of the reported methodologies suffer from one or more of the following disadvantages: (1) potential health hazards associated with the preparation of the catalysts (e.g., pyridine is flammable and has a flash point of $17^{\circ} \mathrm{C}$ ); (2) difficulty in handling the catalysts (e.g., triflates are moisture-sensitive); (3) high cost of the catalysts (e.g., triflates); (4) the requirement for halogenated solvents (e.g., $\mathrm{C}_{10} \mathrm{~F}_{18}$ ); (5) difficulties associated with the preparation of the catalysts; (6) the lack of atom economy (i.e., the use of substrates and catalyst in excess); (7) the requirement for stringent reaction conditions and longer reaction time (4-24 h); and (8) in some cases the reported methodologies are not suitable for acid-sensitive substrates.

\section{Conclusions}

We have developed a facile and efficient method for the synthesis of polyhydroquinoline derivatives. There are several advantages associated with this newly developed procedure, including its simple experimental procedure, solvent-free conditions, use of an inexpensive and readily available catalyst, good to high yields, reusability of the catalyst and ease of product isolation/purification by non-aqueous work-up.

\section{Acknowledgments}

The author is thankful to Qaemshahr branch, Islamic Azad University and House Research of Professor Reza, Education Guilan, District 1 for partial support of this work.

\section{References}

[1] Brock E D, Lewis D M, Yousaf T I, Harper H H. WO Patent 9951688. 1999

[2] Sakata G, Makino K, Karasawa Y. Heterocycles 1988, 27: 2481

[3] Demeunynck M, Moucheron C, Mesmaeker A K D. Tetrahedron Lett, 2002, 43: 261
[4] Ali M M, Tasneem T, Rajanna K C, Prakash P K S. Synlett, 2001: 251

[5] Cho C S, Kim B T, Kim T J, Shim S C. Chem Commun, 2001: 2576

[6] Crousse B, Begue J P, Bonnet-Delpon D. J Org Chem, 2000, 65: 5009

[7] Lin X F, Cui S L, Wang Y G. Tetrahedron Lett, 2006, 47: 4509

[8] Beagley P, Blackie M A L, Chibale K, Clarkson C, Meijboom R, Moss J R, Smith P J, Su H. Dalton Trans, 2003: 3046

[9] Sawada Y, Kayakiri H, Abe Y, Mizutani T, Inamura N, Asano M, Hatori C, Aramori I, Oku T, Tanaka H.J Med Chem, 2004, 47: 2853

[10] Ma Z Z, Hano Y, Nomura T, Chen Y J. Bioorg Med Chem Lett, 2004, 14: 1193

[11] Denton T T, Zhang X D, Cashman J R. J Med Chem, 2005, 48: 224

[12] Fokialakis N, Magiatis P, Chinou I, Mitaku S, Tillequin F. Chem Pharm Bull, 2002, 50: 413

[13] Fossa P, Mosti L, Menozzi G, Marzano C, Baccichetti F, Bordin F. Bioorg Med Chem, 2002, 10: 743

[14] Ryckebusch A, Deprez-Poulain R, Maes L, Debreu-Fontaine M A, Mouray E, Grellier P, Sergheraert C. J Med Chem, 2003, 46: 542

[15] Morgan L R, Jursic B S, Hooper C L, Neumann D M, Thangaraj K, LeBlanc B. Bioorg Med Chem Lett, 2002, 12: 3407

[16] Kouznetsov V V. Tetrahedron, 2009, 65: 2721

[17] Haghighi M G, Rashidi M, Nabavizadeh S M, Jamali S, Puddephatt R J. Dalton Trans, 2010, 39: 11396

[18] Baratta W, Fanfoni L, Magnolia S, Siega K, Rigo P. Eur J Inorg Chem, 2010: 1419

[19] Mauzerall D, Westheimer F H.J Am Chem Soc, 1955, 77: 2261

[20] Godfraind T, Miller R, Mibo M. Pharmacol Rev, 1986, 38: 321

[21] Stout D M, Meyers A I. Chem Rev, 1982, 82: 223

[22] Janis R A, Triggle D J.J Med Chem, 1983, 26: 775

[23] Bossert F, Mayer H, Wehinger E. Angew Chem Int Ed, 1981, 20: 762

[24] Toussaint C, De Pauw L, Vienne A, Gevenois P A, Quintin J, Gelin M, Pasteels J L. Am J Kidney Dis, 1993, 21: 54

[25] Kawase M, Shah A, Gaveriya H, Motohashi N, Sakagami H, Varga A, Molnar J. Bioorg Med Chem, 2002, 10: 1051

[26] Ladani N K, Mungra D C, Patel M P, Patel R G. Chin Chem Lett, 2011, 22: 1407

[27] Wang S X, Li Z Y, Zhang J C, Li J T. Ultrason Sonochem, 2008, 15: 677

[28] Wang L M, Sheng J, Zhang L, Han J W, Fan Z Y, Tian H, Qian C T.

\section{Graphical Abstract}

Chin. J. Catal., 2014, 35: 1036-1042 doi: 10.1016/S1872-2067(14)60038-3

Four-component one-pot synthesis of unsymmetrical polyhydroquinoline derivatives using 3-methyl-1-sulfonic acid imidazolium hydrogen sulfate as a catalyst

Nader Ghaffari Khaligh*

Qaemshahr Branch, Islamic Azad University, Iran; Research House of Professor Reza, Education Guilan, Iran

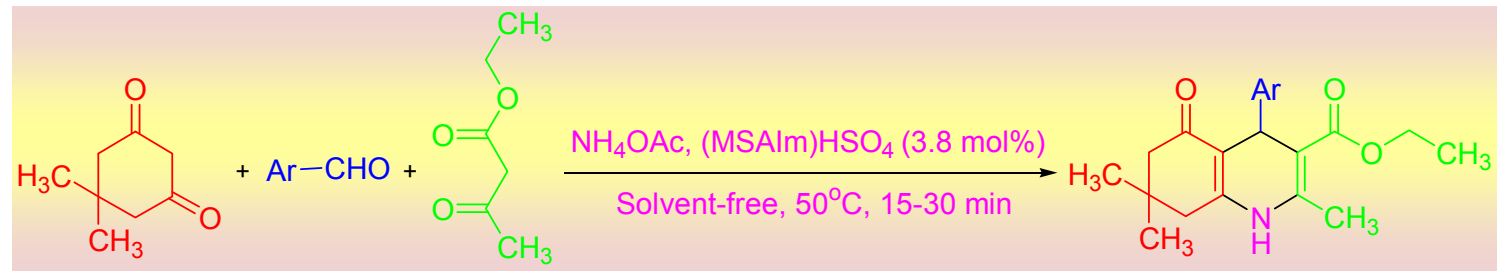

One-pot condensation of dimedone with aryl/heteryl aldehydes, ethyl acetoacetate and ammonium acetate in the presence of 3-methyl1 -sulfonic acid imidazolium hydrogen sulfate under solvent-free conditions. The catalyst could be recycled and reused at least four times without any significant loss in its activity. The structures of the new products were established from their spectral properties (IR, $1 \mathrm{H}$ NMR, and MS), as well as their melting point and elemental analysis data. The known products were characterized by their physical data (m.p., IR, ${ }^{1} \mathrm{H}$ NMR) and through a comparison with the authentic samples. 
Tetrahedron, 2005, 61: 1539

[29] Kumar A, Maurya R A. Tetrahedron, 2007, 63: 1946

[30] Undale K A, Shaikh T S, Gaikwad D S, Pore D M. C R Chim, 2011, 14: 511

[31] Ji S J, Jiang Z Q Lu J, Loh T P. Synlett, 2004: 831

[32] Maheswara M, Siddaiah V, Damu V G L, Rao C V. Arkivoc, 2006: 201

[33] Sapkal S B, Shelke K F, Shingate B B, Shingare M S. Tetrahedron Lett, 2009, 50: 1754

[34] Katkar S S, Mohite P H, Gadekar L S, Arbad B R, Lande M K. Green Chem Lett Rev, 2010, 3: 287

[35] Safari J, Banitaba S H, Khalili S D. J Mol Catal A, 2011, 335: 46

[36] Ko S, Sastry M N V, Lin C, Yao C F. Tetrahedron Lett, 2005, 46: 5771

[37] Parvulescu V I, Hardacre C. Chem Rev, 2007, 107: 2615

[38] Rogers R D, Seddon K R. Ionic Liquids: Industrial Application to Green Chemistry. Washington DC: Am Chem Soc, 2002

[39] Miao C X, He L N, Wang J Q, Wang J L. Adv Synth Catal, 2009, 351: 2209

[40] Cole A C, Jensen J L, Ntai I, Tran K L T, Weaver K J, Forbes D C, Davis J H Jr. J Am Chem Soc, 2002, 124: 5962

[41] Arfan A, Bazureau J P. Org Process Res Dev, 2005, 9: 743

[42] Wasserscheid P, Sesing M, Korth W. Green Chem, 2002, 4: 134

[43] Wasserscheid P, van Hal R, Bösmann A. Green Chem, 2002, 4: 400

[44] Fraga-Dubreuil J, Bourahla K, Rahmouni M, Bazureau J P, Hamelin J. Catal Commun, 2002, 3: 185

[45] Gathergood N, Garcia M T, Scammells P J. Green Chem, 2004, 6: 166

[46] Garcia M T, Gathergood N, Scammells P J. Green Chem, 2005, 7: 9

[47] Gu Y L, Zhang J, Duan Z Y, Deng Y Q. Adv Synth Catal, 2005, 347: 512
[48] Kalita P, Kumar R. Microporous Mesoporous Mater, 2012, 149: 1

[49] Khaligh N G.J Mol Catal A, 2011, 349: 63

[50] Khaligh N G. Catal Sci Technol, 2012, 2: 1633

[51] Cave G W V, Raston C L, Scott J L. Chem Commun, 2001: 2159

[52] Nagarapu L, Kumari M D, Kumari N V, Kantevari S. Catal Commun, 2007, 8: 1871

[53] Saikia L, Dutta D, Dutta D K. Catal Commun, 2012, 19: 1

[54] Baghbanian S M, Khaksar S, Mohammad-Vahdat S, Farhang M, Tajbakhsh M. Chin Chem Lett, 2010, 21: 563

[55] Khojastehnezhad A, Moeinpour F, Davoodnia A. Chin Chem Lett, 2011, 22, 807

[56] Khazaei A, Zolfigol M A, Moosavi-Zare A R, Afsar J, Zare A, Khakyzadeh V, Beyzavi M H. Chin J Catal (催化学报), 2013, 34: 1936

[57] Heydari A, Khaksar S, Tajbakhsh M, Bijanzadeh H R. J Fluorine Chem, 2009, 130: 609

[58] Hong M, Cai C, Yi W B. J Fluorine Chem, 2010, 131: 111

[59] Surasani R, Kalita D, Rao A V D, Yarbagi K, Chandrasekhar K B. J Fluorine Chem, 2012, 135: 91

[60] Donelson J L, Gibbs R A, De S K.J Mol Catal A, 2006, 256: 309

[61] Heravi M M, Bakhtiari K, Javadi N M, Bamoharram F F, Saeedi M, Oskooie H A.J Mol Catal A, 2007, 264: 50

[62] Tajbakhsh M, Alinezhad H, Norouzi M, Baghery S, Akbari M. J Mol Liq, 2013, 177: 44

[63] Ko S, Yao C F. Tetrahedron, 2006, 62: 7293

[64] Kumar A, Maurya R A. Tetrahedron Lett, 2007, 48: 3887

[65] Sapkal S B, Shelke K F, Shingate B B, Shingare M S. Tetrahedron Lett, 2009, 50: 1754

[66] Saha M, Pal A K. Tetrahedron Lett, 2011, 52: 4872

[67] Zare A, Abi F, Moosavi-Zare A R, Beyzavi M H, Zolfigol M A. J Mol Liq, 2013, 178: 113 